ノート

高機能性オオムギ品種育成のための $\beta$-グルカン高含有育種素材の選定と特性評価 塔野岡卓司 ${ }^{1,2)}$ ・河田尚之 ${ }^{1,3)}$ ・荒木 均 1,4$)$

1) 九州沖縄農業研究センタ一筑後・久留米研究拠点, 筑後市, 干 833-0041

2) 現：農業・食品産業技術総合研究機構本部，つくば市，３ 305-8517

3) 現: 京都学園大学バイオ環境学部, 亀岡市, 干 $621-8555$

4) 現 : 筑後市, $=833-0005$

\title{
Screening and evaluation of genetic resources containing high level of $\beta$-glucan for breeding of barley cultivars for functional foods
}

\author{
Takuji Tonooka ${ }^{1,2)}$, Naoyuki Kawada ${ }^{1,3)}$ and Hitoshi Araki ${ }^{1,4)}$ \\ 1) Chikugo Research Station, NARO Kyushu Okinawa Agricultural Research Center, Chikugo 833-0041, Japan \\ 2) Present address: Headquarters of NARO, Tsukuba 305-8517, Japan \\ 3) Present address: Faculty of Bioenvironmental Science, Kyoto Gakuen University, Kameoka 621-8555, Japan \\ 4) Present address: Chikugo 833-0005, Japan
}

キーワード

Hordeum vulgare，オオムギ，機能性多糖， $\beta$-グルカン，加工適性，育種素材

\section{緒 言}

オオムギはその穀粒中にへミセルロースの一種である

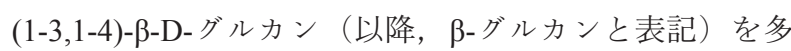
く含む穀物である (Henry 1987). オオムギの $\beta$-グルカン には血糖値の上昇抑制（Liljeberg et al. 1996, Yokoyama et al. 1997, Bourdon et al. 1999, Cavallero et al. 2002)，血中ב レステロールの低減 (Newman et al. 1989, McIntosh et al. 1991, Bourdon et al. 1999, Behall et al. 2004a, 2004b, Pins et al. 2005), 血圧降下 (Hallfrisch et al. 2003, Behall et al. 2006), 免疫機能の活性化（Tada et al. 2008）などのヒト に打ける生理調整機能が報告されて扣り, アメリカ合衆 国や欧州連合では，オオムギを含む食品に対して，冠状 動脈心疾患の予防効果がある旨のヘルスクレーム（健 康強調表示）を許可している（U.S. Food and Drug Administration 2006, European Food Safety Authority 2009)。日本でも，2015 年度から始まった機能性表示食 品制度に执いて，糖質吸収抑制，コレステロール值改善， 腸内環境改善の機能性を謳ったオオムギ食品の申請が相 次ぎ， 2018 年 3 月現在で 11 製品が受理されている（消 費者庁機能性表示食品制度届出データベース)。また，近

編集委員 : 辻本 壽

2018 年 6 月 27 日受領 2018 年 9 月 3 日受理

2018 年 10 月 16 日 J-STAGE 早期公開

Correspondence: tohnooka@affrc.go.jp
年では, 内蔵脂肪の低減 (Aoe et al. 2017), 便通の改善 (Taniguchi et al. 2017), 満腹感の持続（Aoe et al. 2014）, セカンドミール効果（福原ら 2013）について, 日本人に 拈けるエビデンスが得られている。 日本では, 糖尿病, 高血圧性疾患, 高脂血症の患者数がそれぞれ 316 万人, 1,010 万人， 206 万人に達するなど（厚生労働省大臣官房 統計情報部 2015), 生活習慣病罹患率が増加して未り, オオムギは生活習慣病の予防と改善に有用な食材である と考えられる.オオムギの付加価值を高め，新たな用途 開発と需要拡大による大麦作の収益性向上を図るために は， $\beta$-グルカン含量をさらに高めた品種の開発が重要で ある。

オオムギに拈ける $\beta$-グルカン合成の鍵遺伝子はセル ロース合成酵素様遺伝子の一つ H C s lF 6 であることが解 明されたが（Tonooka et al. 2009, Taketa et al. 2012）， $\beta$-グ ルカン合成に関わる遺伝子の全容や合成量調節に関わる 遺伝子はなお不明であるため，筆者らは，デンプンの合

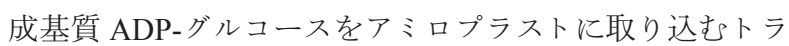
ンスポーターの変異遺伝子 lys5h（Patron et al. 2004）が $\beta$-グルカン含量を大幅に高めることを利用し（塔野岡 2010)，一般的な品種の 2 倍以上の $\beta$-グルカンを含む先 行的品種「ビューファイバー」を育成した(塔野岡ら 2011).

しかし，「ビューファイバー」ではデンプン合成が抑制 されることにより穀粒の充実が劣り収量性が低いほか, 穀粒が硬く精白後の色相も劣るなど精麦加工適性が低い 欠点があるため（塔野岡ら 2011）, 用途が主に粉体利用 
に制限されるなど沉用性を欠き，限定的な普及・利用に 留まっている。 また，オオムギの加工販売に携わる実需 者は，麦飯等の従来用途から大麦粉やシリアル食品など の新規用途まで利用可能な高 $\beta$-グルカン品種を要望して いるため，穀粒の充実不良などの加工適性に影響するよ らな不良形質がなく，一般的な精麦用品種と同等以上の 収量性を持ち，麦飯だけでなく大麦粉やシリアル食品ま で利用可能な汎用性のある高 $\beta$-グルカン品種を育成する 必要がある。しかし， $\beta$-グルカン含量が高いとされるオ オムギ遺伝資源については，国内外で報告や保存がある が，高 $\beta$-グルカン品種に関する統一された含量基準はな く，また，それらを同一条件で同時に栽培して比較した 報告は見当たらない，そこで，高 $\beta$-グルカン含量とされ る品種・系統について, 栽培性, $\beta$-グルカン含量, 加工 適性に関わる品質について特性評価を行い, 高 $\beta$-グルカ ン品種育成のための有望な育種素材を明らかにした.

\section{材料および方法}

\section{1. 供試品種・系統}

$\beta$-グルカン高含有育種素材の選定に当たり，2012 年度 （播種年度，以降同様）飞予備選抜を，2013 年度に特性 評価を行った，供試品種・系統一覧を表 1 飞示す。アメ リカ合衆国農務省農業調査局（Agricultural Research Service, United States Department of Agriculture）の国立植 物遺伝資源システム（National Plant Germplasm System） にて保存されているオオムギ遺伝資源のらち, 高 $\beta$-グル カン含量との特性表記がある「Azhul」,「Jao」,「Jau」, $\lceil$ Oowa $\rfloor,\lceil$ Shonkin」, 「Tsema」, 「Wanubet」の 7 品種拈よ びカナダ穀物委員会（Canadian Grain Commission）に抒 いて高 $\beta$-グルカン含量品種と定義されている「CDCAlamo $」 と 「$ CDC-Fibar $」$ (Canadian Grain Commission 2015)，高 $\beta$-グルカン含量系統との報告のある「STWB-1」 （塔野岡 2010）の合計 10 品種・系統を供試した。同時 に，比較品種・系統として，デンプンの合成や組成に関 する突然変異遺伝子を利用して育成された高 $\beta$-グルカン 4 品種・系統（「ビューファイバー」，「関東裸糯 94 号（の ちの「ワキシーファイバー」)」,「四系 9519」, 「関系 n574 （旧系統名：谷系 QM-1）」）を供試した（「関系 n574」は 2013 年度の夕)。「関東裸糯 94 号」はlys $5 h$ 遺伝子と糯性 遺伝子 wax を持つ系統で,「ビューファイバー」よりも $\beta$-グルカン含量が高い（柳澤ら 2016）。「四系 9519」は高 アミロース遺伝子 amol（Eslick and Ullrich 1977）と糯性 遺伝子 wax を持つ系統で（Fujita et al. 1999），糯性遺伝 子と amol 遺伝子の二重変異系統では $\beta$-グルカン含量が 高くなることが報告されている（Swanston et al. 1996）. 「関系 n574」は，「四国裸 84 号」の糯性人為突然変異系 統である「四国裸 97 号」(Ishikawa et al. 1995）飞再度人 為突然変異処理して作出され,「ビューファイバー」より もさらにデンプン含量が低く $\beta$-グルカン含量が高い系統
で（一ノ瀬ら 2015），Lys5 遺伝子座の新規アレルを持つ (中田ら 2018)。これらの比較品種・系統は「四国裸 84 号」の戻し交配や突然変異由来であるなど, 同一の系統 を遺伝的背景とする。 また，参考品種として，粳性に比 ベて $\beta$-グルカン含量が高い糯性オオムギ（Ullich et al. 1986）の「キラリモチ」(Yanagisawa et al. 2011) と「もっ ちりぼし」(円谷ら 2014）の 2 品種を供試した. この他, 粳性の二条オオムギ 2 品種（皮性の「ニシノホシ」と裸 性の「ユメサキボシ」) を標準品種として同時に供試した.

\section{2. 高 $\beta$-グルカン育種素材の予備選抜}

高 $\beta$-グルカン育種素材の予備選抜として，2012 年 11 月 27 日に九州沖縄農業研究センタ一筑後拠点 (福岡県筑 後市）の畑戋場（前作なし）に打いて 17 品種・系統を 1 区畦幅 $70 \mathrm{~cm}$, 畦長 $2.5 \mathrm{~m}$ で株間 $10 \mathrm{~cm}$ 間隔の二条点播に より無反復で栽培した。施肥量は窒素, リン酸, カリで それぞれ $0.4 \mathrm{~kg} / \mathrm{a}, 0.34 \mathrm{~kg} / \mathrm{a}, 0.34 \mathrm{~kg} / \mathrm{a}$ とし, 基肥のみと した。出穂期, 開閉花受粉性の調査を行い, 各品種・系 統とも畦の前後端を除く生育中庸な 3 個体を収穫し, 個 体別に脱穀した後, 未熟粒や充実不良の穀粒を除去して 千粒重を調査した。また，玄麦を粉砕機（Cyclone Sample Mill, UDY) を用いて粒径 $0.5 \mathrm{~mm}$ 以下に粉砕し, 市販キッ 卜 (Mixed Linkage $\beta$-glucan Assay Kit, Megazyme Inc.) を 用いて $\beta$-グルカン含量を測定した.

\section{3. 高 $\beta$-グルカン育種素材の特性評価}

2012 年度に予備選抜用として供試した中から選抜した 品種について, 比較, 参考, 標準品種・系統とともに, 2013 年 11 月 18 日に九州沖縄農業研究センタ一筑後拠点 水田圃場（前作水稲）で, 1 区畦幅 $70 \mathrm{~cm}$, 畦長 $5 \mathrm{~m}$ の条 播により 2 反復で栽培した。な抒，比較系統として $\beta$-グ ルカン含量が著しく高い「関系 n574」も加えて供試し た。施肥量は窒素，リン酸，カリで，基肥ではそれぞれ $0.6 \mathrm{~kg} / \mathrm{a}, 0.51 \mathrm{~kg} / \mathrm{a}, 0.51 \mathrm{~kg} / \mathrm{a}$, 追肥ではそれぞれ $0.2 \mathrm{~kg} / \mathrm{a}, 0.17 \mathrm{~kg} / \mathrm{a}, 0.17 \mathrm{~kg} / \mathrm{a}$ とした. 出穂期, 成熟期, 㷏長, 穂長, 穂数を調査するとともに, 収穫後風選した 穀粒を用いて収量を測定し，二条オオムギのうち皮性で は $2.5 \mathrm{~mm}$ 以上, 裸性では $2.2 \mathrm{~mm}$ 以上, 六条才オムギの 裸性では $2.0 \mathrm{~mm}$ 以上の整粒歩合を測定した。ただし， 品質分析に当たって, 穀粒の充実が著しく劣る特性のあ る「ビューファイバー」,「関東裸糯 94 号」,「四系 9519」, 「関系 n574」については，歩留 $80 \%$ 以上を確保できるよ らな篩い目を選定して縦目篩いで粒選し，未熟粒や充実 不良の穀粒を除いて試料とした，精麦加工品質に関わる 粒形質として, 千粒重, 容積重, 硝子率（ハインスドル フ式穀粒横断器を用いて 50 粒を横断し, 目視判定で硝子 質粒，半硝子質粒，粉状質粒に分別し，硝子質粒+半硝 子質粒 $\times 1 / 2$ の值を調査粒数で除して算出）を測定すると ともに，単粒硬度計（SKCS-4100, Perten）を用いて穀粒 硬度を測定した.また，玄麦を粉研機 (Cyclone Sample Mill, 
表 1. 供試品種・系統一覧

\begin{tabular}{|c|c|c|c|c|c|c|}
\hline $\begin{array}{l}\text { 品種名 } \\
\text { 系統名 }\end{array}$ & 系譜 & 育成機関 & 条性 & 皮裸性 & 糯粳性 & $\begin{array}{l}\text { その他の } \\
\text { 穀粒形質 }{ }^{11}\end{array}$ \\
\hline STWB-1 & 二条モチ麦/関東二条 22 号 & サッポロビール（株） & 二条 & 皮 & 糯 & \\
\hline CDC-Alamo & SB85750/Arizona Hulless Waxy & カナダ・サスカチュワン大学 & 二条 & 裸 & 糯 & \\
\hline CDC-Fibar & SB94789/SB94892 & カナダ・サスカチュワン大学 & 二条 & 裸 & 糯 & \\
\hline Shonkin & Wanubetより純系分離 & アメリカ・モンタナ州立大学 & 二条 & 裸 & 糯 & \\
\hline Wanubet & Betzes*7/Waxy Oderbrucker//Nubet & アメリカ・モンタナ州立大学 & 二条 & 裸 & 糯 & \\
\hline Azhul & 76-19-7 の突然変異 & アメリカ・アリゾナ大学 & 六条 & 裸 & 糯 & \\
\hline Jao & インド・ウッタルプラデーシュ州の在来品種 & - & 六条 & 裸 & 粳 & \\
\hline Jau & インド・パンジャブ州の在来品種 & - & 六条 & 裸 & 粳 & \\
\hline Oowa & インド・ウッタルプラデーシュ州の在来品種 & - & 六条 & 裸 & 粳 & \\
\hline Tsema & インド・ウッタルプラデーシュ州の在来品種 & - & 六条 & 裸 & 粳 & \\
\hline \multicolumn{7}{|c|}{ 比較品種・系統（デンプン変異による高 $\beta$-グルカン品種・系統） } \\
\hline ビューファイバー & 四国裸 84 号*4/Riso 86 & （国研）農研機構・作物研究所 & 二条 & 裸 & 粳 & lys $5 h$ \\
\hline 関東裸糯 94 号 & 四国裸 84 号 (lys5h) $\mathrm{BC}_{4} /$ 四国裸 97 号 & （国研）農研機構・作物研究所 & 二条 & 裸 & 糯 & lys $5 h$ \\
\hline 関系 n574²) & 四国裸 97 号の突然変異 & （国研）農研機構・作物研究所 & 二条 & 裸 & 糯 & lys5? \\
\hline 四系 9519 & 四国裸 97 号/四 M286/Glacier AC38//四 M286 & 農林水産省・四国農業試験場 & 二条 & 裸 & 糯 & amol \\
\hline \multicolumn{7}{|c|}{ 参考品種（糯性品種） } \\
\hline キラリモチ & 四国裸 103 号/大系 HL107//四国裸 97 号 & $\begin{array}{l}\text { （国研）農研機構・近畿中国四国農業 } \\
\text { 研究センター }\end{array}$ & 二条 & 裸 & 糯 & ant 28 \\
\hline もっちりぼし & 羽系裸 104/あぐりもち & サッポロビール（株） & 二条 & 裸 & 糯 & \\
\hline \multicolumn{7}{|c|}{ 標準品種（粳性品種） } \\
\hline ニシノホシ & 西海皮 38 号/栃系 145 & 農林水産省・九州農業試験場 & 二条 & 皮 & 粳 & \\
\hline ユメサキボシ & 四 R 系 833/ニシノチカラ & $\begin{array}{l}\text { （国研）農研機構・近畿中国四国農業 } \\
\text { 研究センター }\end{array}$ & 二条 & 裸 & 粳 & \\
\hline
\end{tabular}

1) lys5h: ADP-グルコーストランスポーターをコードするLys5 遺伝子座の变異アリル, lys5? : Lys5 遺伝子座の新規変異アリル, amol : 高アミロース, ant $28:$ プロアントシアニジンフリー.

2) 2013 年度の久供試.

Udy）を用いて粒径 $0.5 \mathrm{~mm}$ 以下に粉砕し， $\beta$-グルカン含 量打よびデンプン含量をそれぞれ市販キット（Mixed Linkage $\beta$-glucan Assay Kit, Total Starch Assay Kit, Megazyme Inc.）を用いて測定した. 玄麦タンパク質含量 は非破壊の全粒で近赤外分光分析機（Infratec 1275, FOSS）を用いて測定した. さらに, 試験用搗精機 (TM-05, 佐竹製作所）を用い，玄麦 $150 \mathrm{~g}$ を歩留 55\%（裸麦は 60\%）まで搗精し, 搗精時間, 精麦白度（ケット科学, C-300-3)，精麦色相（CM-3500d，コニカミノルタジャパ ン), 砕粒率を測定するとともに, 玄麦 $\beta$-グルカンと同様 の方法で精麦 $\beta$-グルカン含量を測定した.

\section{結果および考察}

\section{1. 高 $\beta$-グルカン育種素材の予備選抜}

予備選抜に供試した 17 品種・系統の特性を表 2 に示 す。粳性の一般的な品種「ニシノホシ」と「ユメサキボ シ」の玄麦 $\beta$-グルカン含量はそれぞれ $3.8 \%, 3.7 \%$ であっ たのに対し，デンプン変異による高 $\beta$-グルカン品種・系 統である「ビューファイバー」,「関東裸糯 94 号」,「四系 9519」では 9.9 13.7\%で，「関東裸糯 94 号」が最も $\beta$-グ ルカン含量が高かった.
選抜対象の 10 品種・系統のうち, 「STWB-1」のみが 閉花受粉性で，「STWB-1」，「Jau」，「Oowa」，「Tsema」は 「ユメサキボシ」よりも出穂期が早いか同等の早生であっ た.「CDC-Fibar」と「Azhul」は「ユメサキボシ」よりも 出穂期が遅い晚生であるが， $\beta$-グルカン含量はそれぞれ $10.0 \%, 9.4 \%$ で，「四系 9519」と同程度の高含量であっ た.「STWB-1」と「CDC-Alamo」の $\beta$-グルカン含量はと もに $7.2 \%$ ，糯性の「キラリモチ」と「もっちりぼし」 の中間程度であったが，大粒であった，粳性品種の中で

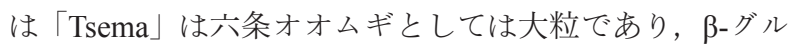
カン含量が 7.0\%と粳性としては高かった.「Shonkin」と $\lceil$ Wanubet」の $\beta$-グルカン含量は「STWB-1」,「CDCAlamo」と同程度であるが，千粒重が「ユメサキボシ」 程度であった。「Jao」と「Jau」は $\beta$-グルカン含量が低 く,「Oowaは「Tsema」よりも千粒重が軽かった.

以上の結果から, 早晚性, 千粒重, $\beta$-グルカン含量, 糯性を判断基準として, 「STWB-1」,「CDC-Alamo」,「CDCFibar」,「Azhul」の 4 品種・系統を有望として選抜した. オオムギの糯性品種は粳性品種に比べて $\beta$-グルカン含量 が高く（Ullrich et al. 1986），炊飯麦の粘りが大きく，食 味が優れるため（吉川ら 1998），高 $\beta$-グルカン品種育成 に执いて有用である。な报，糯性ではないが，粳性とし 
表 2. 高 $\beta$-グルカン品種・系統の予備選抜（2012 年度）

\begin{tabular}{|c|c|c|c|c|c|}
\hline $\begin{array}{l}\text { 品種名 } \\
\text { 系統名 }\end{array}$ & $\begin{array}{l}\text { 出穂期 } \\
\text { (月.日) }\end{array}$ & 開閉花受粉性 & $\begin{array}{c}\text { 千粒重 } \\
(\mathrm{g})\end{array}$ & $\begin{array}{c}\text { 立麦 } \beta \text {-グルカン含量 } \\
(\%)^{1)}\end{array}$ & 選抜 \\
\hline STWB-1 & 4.08 & 閉花 & $54.0^{\mathrm{cd} 2)}$ & $7.2^{\text {cde3) }}$ & $\bigcirc$ \\
\hline CDC-Alamo & 4.28 & 開花 & $47.7^{\mathrm{bcd}}$ & $7.2^{\text {cde }}$ & $\bigcirc$ \\
\hline CDC-Fibar & 4.25 & 開花 & $39.3^{a b}$ & $10.0^{\mathrm{ef}}$ & $\bigcirc$ \\
\hline Shonkin & 4.28 & 開花 & $41.4 \mathrm{abc}$ & $7.4^{\text {cde }}$ & $x$ \\
\hline Wanubet & 4.27 & 開花 & $41.9^{a b c}$ & $7.1^{\text {cde }}$ & $\times$ \\
\hline Azhul & 4.26 & 開花 & $38.5^{\mathrm{ab}}$ & $9.4^{\text {def }}$ & $\bigcirc$ \\
\hline Jao & 4.21 & 開花 & $45.2^{\text {bed }}$ & $5.9^{a b c}$ & $\times$ \\
\hline Jau & 4.11 & 開花 & $43.7^{\mathrm{abcd}}$ & $5.4^{\mathrm{abc}}$ & $x$ \\
\hline Oowa & 4.08 & 開花 & $36.0^{\mathrm{ab}}$ & 7.0 bcde & $\times$ \\
\hline Tsema & 4.09 & 開花 & $39.4^{\mathrm{ab}}$ & 7.0 bcde & $\bigcirc$ \\
\hline ビューファイバー & 4.29 & 開花 & $32.2^{\mathrm{a}}$ & $11.1^{\mathrm{fg}}$ & - \\
\hline 関東裸糯 94 号 & 4.18 & 開花 & $35.3^{\mathrm{ab}}$ & $13.7^{\mathrm{g}}$ & - \\
\hline 四系 9519 & 4.15 & 開花 & $40.0^{\mathrm{ab}}$ & $9.9^{\text {ef }}$ & - \\
\hline キラリモチ & 4.05 & 開花 & $43.6^{\text {abcd }}$ & 6.4 abcd & - \\
\hline もっちりぼし & 4.09 & 閉花 & $47.6^{\text {bcd }}$ & 8.2 cdef & - \\
\hline ニシノホシ & 4.03 & 閉花 & $55.3^{\mathrm{d}}$ & $3.8^{\mathrm{ab}}$ & - \\
\hline ユメサキボシ & 4.11 & 閉花 & $42.5^{\text {abcd }}$ & $3.7^{\mathrm{a}}$ & - \\
\hline
\end{tabular}

ては $\beta$-グルカン含量の高い「Tsema」も選抜した。さら 飞詳細な特性評価試験の供試対象として, 以上の 5 品種・ 系統を選定した

\section{2. 高 $\beta$-グルカン育種素材の特性評価}

供試した 13 品種・系統の生育特性を表 3 亿, 玄麦品質 を表 4 亿，精麦品質を表 5 に示す。デンプン変異による 高 $\beta$-グルカン品種・系統である「ビューファイバー」,「関 東裸糯 94 号」,「関系 n574」,「四系 9519」では, $\beta$-グル カン含量が 9.8〜 $13.3 \%$ と高かったが，タンパク質含量も
$13.1 \sim 15.6 \%$ と高く, デンプン含量が $35.4 \sim 51.2 \%$ と低く, 完熟した穀粒は收縮した形状を呈して表面にしわを生じ, 穀粒の充実が不良なため整粒歩合が $65.4 \%$ 以下と低かっ

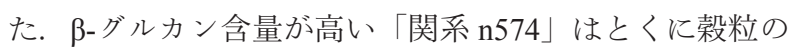
充実が不良で, 粒厚 $2.2 \mathrm{~mm}$ 以上の整粒が存在しなかっ た.こ机らの品種・系統の $\beta$-グルカン含量が高い理由と して, デンプンと $\beta$-グルカンは合成基質がともにグルコー スであるため（Bolwell 2000），デンプン合成の減少によ りデンプン合成の基質として利用されなかった余剩のグ ルコースが $\beta$-グルカンの合成経路に転流されて補償的に

表 3. 高 $\beta$-グルカン品種・系統の生育特性（2013 年度）

\begin{tabular}{|c|c|c|c|c|c|c|c|}
\hline $\begin{array}{l}\text { 品種名 } \\
\text { 系統名 }\end{array}$ & $\begin{array}{l}\text { 出穂期 } \\
\text { (月.日) }\end{array}$ & $\begin{array}{l}\text { 成熟期 } \\
\text { (月.日) }\end{array}$ & $\begin{array}{l}\text { 秙長 } \\
(\mathrm{cm})\end{array}$ & $\begin{array}{l}\text { 穂長 } \\
(\mathrm{cm})\end{array}$ & $\begin{array}{c}\text { 穂数 } \\
\left(\text { 本 } / \mathrm{m}^{2}\right)\end{array}$ & $\begin{array}{l}\text { 収量 } \\
\text { (kg/a) }\end{array}$ & $\begin{array}{c}\text { 整粒歩合 } \\
(\%)^{1)}\end{array}$ \\
\hline STWB-1 & $3.30^{\mathrm{a}}$ & $5.12^{\mathrm{a}}$ & $99 \mathrm{bc}$ & $6.8^{a b}$ & $586^{a}$ & $43.5^{\mathrm{a}}$ & $94.3^{c}$ \\
\hline CDC-Alamo & $4.16^{\mathrm{a}}$ & $5.21^{\text {a }}$ & $104^{b c}$ & $9.5^{\mathrm{c}}$ & $693^{a}$ & $65.8^{\mathrm{a}}$ & $95.8^{\mathrm{c}}$ \\
\hline CDC-Fibar & $4.13^{\mathrm{a}}$ & $5.21^{\text {a }}$ & $115^{c}$ & $8.4^{\mathrm{bc}}$ & $676^{\mathrm{a}}$ & $61.8^{\text {a }}$ & $96.1^{\mathrm{c}}$ \\
\hline Azhul & $4.11^{\mathrm{a}}$ & $5.23^{\mathrm{a}}$ & $90^{a b}$ & $5.8^{\mathrm{a}}$ & $490^{a}$ & $48.5^{\text {a }}$ & $85.5^{b c}$ \\
\hline Tsema & $3.31^{\mathrm{a}}$ & $5.16^{\mathrm{a}}$ & $112^{c}$ & $7.6^{\mathrm{abc}}$ & $412^{\mathrm{a}}$ & $44.6^{\mathrm{a}}$ & $88.2^{b c}$ \\
\hline ビューファイバー & $4.01^{\mathrm{a}}$ & $5.16^{\mathrm{a}}$ & $87^{a b}$ & $8.4^{\mathrm{bc}}$ & $586^{\mathrm{a}}$ & $40.5^{\text {a }}$ & $49.7^{b}$ \\
\hline 関東裸糯 94 号 & $4.03^{\mathrm{a}}$ & $5.17^{\mathrm{a}}$ & $87^{a b}$ & $8.4^{\mathrm{bc}}$ & $679^{a}$ & $49.1^{\mathrm{a}}$ & $56.8^{b c}$ \\
\hline 関系 n574 & $4.07^{\mathrm{a}}$ & $5.18^{\mathrm{a}}$ & $80^{a}$ & $8.0^{\mathrm{abc}}$ & $646^{\mathrm{a}}$ & $32.1^{\mathrm{a}}$ & $0.0^{\mathrm{a}}$ \\
\hline 四系 9519 & $4.04^{\mathrm{a}}$ & $5.17^{\text {a }}$ & $88^{a b}$ & 7.8 abc & $547^{\mathrm{a}}$ & $42.5^{\mathrm{a}}$ & $65.4^{b c}$ \\
\hline キラリモチ & $3.30^{\mathrm{a}}$ & $5.15^{\mathrm{a}}$ & $80^{a}$ & $7.5^{\mathrm{abc}}$ & $541^{\mathrm{a}}$ & $43.5^{\mathrm{a}}$ & $93.6^{c}$ \\
\hline もっちりぼし & $4.03^{\mathrm{a}}$ & $5.15^{\text {a }}$ & $101 \mathrm{bc}$ & $7.0^{a b}$ & $707^{\text {a }}$ & $55.0^{\mathrm{a}}$ & $90.9^{\mathrm{c}}$ \\
\hline ニシノホシ & $3.28^{\mathrm{a}}$ & $5.14^{\mathrm{a}}$ & $86^{\mathrm{ab}}$ & $7.4^{\mathrm{abc}}$ & $614^{\mathrm{a}}$ & $36.7^{\mathrm{a}}$ & $83.2^{\mathrm{bc}}$ \\
\hline ユメサキボシ & $4.08^{\mathrm{a}}$ & $5.19^{\mathrm{a}}$ & $92^{a b}$ & $7.5^{\mathrm{abc}}$ & $648^{a}$ & $67.4^{\mathrm{a}}$ & $96.6^{c}$ \\
\hline
\end{tabular}

各形質に抢いて異なる文字を付した数值間には $5 \%$ 水準で有意な差があることを示す（Tukey 法).

1) 二条オオムギでは皮性 $2.5 \mathrm{~mm}$ 以上，裸性 $2.2 \mathrm{~mm}$ 以上，六条オオムギ（裸性） $2.0 \mathrm{~mm}$ 以上の粒厚の穀粒の割合. 
表 4. 高 $\beta$-グルカン品種・系統の玄麦品質（2013 年度）

\begin{tabular}{|c|c|c|c|c|c|c|c|}
\hline \multirow{2}{*}{$\begin{array}{l}\text { 品種名 } \\
\text { 系統名 }\end{array}$} & \multirow{2}{*}{ 千粒重（g） } & \multirow{2}{*}{ 容積重（g/l） } & \multirow{2}{*}{ 硝子率（\%） } & \multirow{2}{*}{ 穀粒硬度（HI） } & \multicolumn{3}{|c|}{ 玄麦成分含量（\%）1) } \\
\hline & & & & & タンパク質 & $\beta$-グルカン & デンプン \\
\hline STWB-1 & $45.2^{\mathrm{e}}$ & $741 \mathrm{ab}$ & $15.7^{\mathrm{ab}}$ & $73.5^{\mathrm{abcd}}$ & $11.0^{\mathrm{a}}$ & $7.3^{a b c}$ & $57.0^{\mathrm{bcd}}$ \\
\hline CDC-Alamo & $45.5^{\mathrm{e}}$ & $805^{\mathrm{ab}}$ & $5.9^{\text {a }}$ & $64.4^{\mathrm{abc}}$ & $11.0^{\mathrm{a}}$ & $6.7^{\mathrm{abc}}$ & $63.8^{\mathrm{cd}}$ \\
\hline CDC-Fibar & $39.3^{\mathrm{cd}}$ & 811 ab & $13.6^{\mathrm{ab}}$ & $81.5^{\text {abcd }}$ & $11.7^{\mathrm{a}}$ & $9.2^{\mathrm{cd}}$ & $61.0^{\mathrm{bcd}}$ \\
\hline Azhul & $33.0^{\mathrm{ab}}$ & 784 ab & $16.5^{\mathrm{ab}}$ & $89.9^{\text {bcd }}$ & $9.0^{\mathrm{a}}$ & $7.4 \mathrm{abcd}$ & $61.2^{\mathrm{bcd}}$ \\
\hline Tsema & $31.4^{\mathrm{a}}$ & $839^{\mathrm{b}}$ & $61.0^{\mathrm{abc}}$ & $95.8^{\mathrm{cd}}$ & $9.9^{\text {a }}$ & $6.4^{\mathrm{abc}}$ & $61.7^{\mathrm{cd}}$ \\
\hline ビューファイバー & $36.8^{\mathrm{bc}}$ & $782^{a b}$ & $69.5^{\mathrm{bc}}$ & $90.5^{\mathrm{cd}}$ & $13.1^{\mathrm{a}}$ & $9.8^{\text {cde }}$ & $50.6^{\mathrm{bc}}$ \\
\hline 関東裸糯 94 号 & $37.0^{\mathrm{bc}}$ & 797 ab & $17.5^{a b}$ & 85.9 abcd & $13.3^{\mathrm{a}}$ & $11.4^{\mathrm{de}}$ & $46.3^{\mathrm{ab}}$ \\
\hline 関系 n574 & $30.3^{\mathrm{a}}$ & $705^{a}$ & $82.7^{\mathrm{c}}$ & $107.2^{\mathrm{d}}$ & $15.6^{\mathrm{a}}$ & $13.3^{\mathrm{e}}$ & $35.4^{\mathrm{a}}$ \\
\hline 四系 9519 & $37.8 \mathrm{~cd}$ & 811 ab & $38.7^{\mathrm{abc}}$ & $95.4^{\mathrm{cd}}$ & $13.2^{\text {a }}$ & 9.8 cde & $51.2 \mathrm{bc}$ \\
\hline キラリモチ & $39.5^{\mathrm{cd}}$ & $845^{b}$ & $20.4^{\mathrm{ab}}$ & $79.4^{\text {abcd }}$ & $10.0^{\mathrm{a}}$ & $6.2^{\mathrm{abc}}$ & $65.2^{\mathrm{cd}}$ \\
\hline もっちりぼし & $39.4^{\mathrm{cd}}$ & $831^{\mathrm{b}}$ & 21.1 ab & 75.8 abcd & $11.6^{\mathrm{a}}$ & $7.5^{\text {bcd }}$ & $61.9^{\mathrm{cd}}$ \\
\hline ニシノホシ & $45.4^{\mathrm{e}}$ & 753 ab & $20.3^{\mathrm{ab}}$ & $53.7^{\mathrm{ab}}$ & $8.6^{\mathrm{a}}$ & $3.5^{\mathrm{a}}$ & $67.0^{\mathrm{d}}$ \\
\hline ユメサキボシ & $42.4^{\mathrm{de}}$ & $819^{a b}$ & $27.6^{\mathrm{abc}}$ & $52.7^{\mathrm{a}}$ & $9.8^{\mathrm{a}}$ & $3.7^{\mathrm{ab}}$ & $70.8^{d}$ \\
\hline
\end{tabular}

粒厚を二条オオムギでは皮性 $2.5 \mathrm{~mm}$ 以上，裸性 $2.2 \mathrm{~mm}$ 以上，六条オオムギの裸性では $2.0 \mathrm{~mm}$ 以上に調整した整粒での測定值（ただ

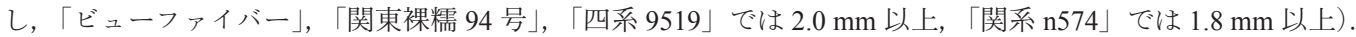

各形質において異なる文字を付した数值間には $5 \%$ 水準で有意な差があることを示す (Tukey 法).

1) 無水物換算での值.

表 5. 高 $\beta$-グルカン品種・系統の精麦品質（2013 年度）

\begin{tabular}{|c|c|c|c|c|c|c|c|}
\hline \multirow{2}{*}{$\begin{array}{l}\text { 品種名 } \\
\text { 系統名 }\end{array}$} & \multirow{2}{*}{$\begin{array}{c}\text { 搗精時間 } \\
\text { (秒) }\end{array}$} & \multirow{2}{*}{$\begin{array}{c}\text { 精麦白度 } \\
(\%)\end{array}$} & \multicolumn{3}{|c|}{ 精麦色相 } & \multirow{2}{*}{$\begin{array}{c}\text { 砕粒率 } \\
(\%)\end{array}$} & \multirow{2}{*}{$\begin{array}{c}\text { 精麦 } \beta-\text { グルカン } \\
(\%)^{1)}\end{array}$} \\
\hline & & & 明度 $\left(\mathrm{L}^{*}\right)$ & 赤又 $\left(\mathrm{a}^{*}\right)$ & 黄色又（b*） & & \\
\hline STWB-1 & 1050 bcde & $46.4^{\mathrm{cd}}$ & $79.9^{b c}$ & $2.3^{\mathrm{ab}}$ & $15.3^{\mathrm{a}}$ & $0.7^{\mathrm{ab}}$ & 8.4 abcd \\
\hline CDC-Alamo & $717^{\mathrm{ab}}$ & $45.7^{\mathrm{cd}}$ & $79.9^{\mathrm{bc}}$ & $2.3^{\mathrm{ab}}$ & $15.2^{\mathrm{a}}$ & $0.3^{\text {a }}$ & $7.5^{\mathrm{abc}}$ \\
\hline CDC-Fibar & 851 abc & $44.8^{\mathrm{bcd}}$ & $78.3^{\mathrm{bc}}$ & $2.2^{\mathrm{ab}}$ & $14.1^{\mathrm{a}}$ & $0.2^{\text {a }}$ & 10.7 bcd \\
\hline Azhul & $1221^{\text {cde }}$ & $45.8^{\mathrm{cd}}$ & $78.0^{\mathrm{bc}}$ & $2.7^{\mathrm{ab}}$ & $13.0^{\mathrm{a}}$ & $0.6^{\mathrm{ab}}$ & $9.2^{\mathrm{bcd}}$ \\
\hline Tsema & $1116^{\text {cde }}$ & $36.7^{\mathrm{a}}$ & $73.0^{\mathrm{ab}}$ & $2.8^{a b}$ & $17.0^{\mathrm{a}}$ & $1.1^{\mathrm{ab}}$ & $6.7^{\mathrm{ab}}$ \\
\hline ビューファイバー & $1283 \mathrm{de}$ & $38.2 \mathrm{ab}$ & $74.1 \mathrm{abc}$ & $3.2^{a b}$ & $16.2^{a}$ & $0.1^{\mathrm{a}}$ & $11.9^{\mathrm{cd}}$ \\
\hline 関東裸糯 94 号 & 1291 de & $41.2^{\mathrm{abcd}}$ & $76.2^{a b c}$ & $2.7^{\mathrm{ab}}$ & $16.0^{\mathrm{a}}$ & $0.0^{\text {a }}$ & 12.8 de \\
\hline 関系 n574 & $1843^{\mathrm{f}}$ & $34.1^{\mathrm{a}}$ & $70.4^{\mathrm{a}}$ & $3.6^{b}$ & $15.0^{\mathrm{a}}$ & $1.2^{\mathrm{ab}}$ & $17.5^{\mathrm{e}}$ \\
\hline 四系 9519 & $1355^{\mathrm{e}}$ & $40.0^{\mathrm{abc}}$ & 75.8 abc & $2.9^{\mathrm{ab}}$ & $15.6^{a}$ & $0.4^{\text {a }}$ & $10.6^{\mathrm{bcd}}$ \\
\hline キラリモチ & 919 abcd & $44.6^{\mathrm{bcd}}$ & $80.1^{\mathrm{c}}$ & $2.1^{\text {a }}$ & $18.0^{\mathrm{a}}$ & $0.4^{\mathrm{a}}$ & $7.5^{a b c}$ \\
\hline もっちりぼし & 964 abcd & $45.6^{\mathrm{cd}}$ & $78.9^{\mathrm{bc}}$ & $2.2^{\mathrm{ab}}$ & $14.1^{\mathrm{a}}$ & $0.5^{\mathrm{a}}$ & $8.3 \mathrm{abcd}$ \\
\hline ニシノホシ & 717 ab & $47.1^{\mathrm{d}}$ & $80.3^{c}$ & $2.2^{a b}$ & $16.4^{\mathrm{a}}$ & $5.5^{\mathrm{c}}$ & $4.1^{\mathrm{a}}$ \\
\hline ユメサキボシ & $659^{\mathrm{a}}$ & $46.4^{\mathrm{cd}}$ & $80.5^{\mathrm{c}}$ & $1.8^{\text {a }}$ & $16.3^{\mathrm{a}}$ & $4.7 \mathrm{bc}$ & $4.1^{\mathrm{a}}$ \\
\hline
\end{tabular}

粒厚を二条オオムギでは皮性 $2.5 \mathrm{~mm}$ 以上，裸性 $2.2 \mathrm{~mm}$ 以上，六条オオムギの裸性では $2.0 \mathrm{~mm}$ 以上に調整した整粒を搗精（ただし，

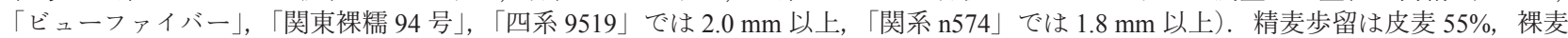
$60 \%$.

各形質に扔いて異なる文字を付した数值間には $5 \%$ 水準で有意な差があることを示す（Tukey 法）.

1) 無水物換算での値.

$\beta$-グルカン含量が増加するものと考兄られる。また，い ずれの品種・系統も穀粒硬度が高くて搗精時間が長く, 精麦白度は 41.2\%以下で，品質ランク区分にお㐨精麦 白度の基準值（六条オオムギおよび裸麦で $43 \%$ 以上，二 条オオムギで $40 \%$ 以上）に満たなかった。 また，精麦の 赤みと黄色みが強く明度が低いが，これは収縮した穀粒 形状により捣精後の糠層の残存が多いことによると考兄 られる.

デンプン変異による高 $\beta$-グルカン品種・系統に対し, 評価対象の 5 品種・系統ではデンプン含量が $57.0 \%$ 以上
で，完熟した穀粒の表面にしわを生じることはなく，整 粒歩合が $85.5 \%$ 以上と高く, 穀粒には形態的な不良形質 は認められなかった。また「Tsema」を除けば，いずれ の品種・系統も精麦白度が $44.8 \%$ 以上と高く, 品質ラン ク区分に招ける精麦白度の基準值を超えた。「STWB-1」 は早生の二条皮麦であり，大粒で品質ランク区分に打け る二条オオムギ容積重の基準值 $709 \mathrm{~g} / 1$ を超えたが， $\beta$-グ ルカン含量は「もっちりぼし」程度であった。「CDCAlamo」は晚生で長秙の二条裸麦で, 穂数が多く大粒で 多収であった，搗精時間が粳性の「ユメサキボシ」と同 
程度に短かったが， $\beta$-グルカン含量は「キラリモチ」程 度であった。「CDC-Fibar」は晚生の二条裸麦で長秙であっ たが, 穂数が多く多収で, $\beta$-グルカン含量が「ビューファ イバー」や「四系 9519」と同程度に高かった。 $\beta$-グルカ ン含量が高い核ど穀粒が硬質となって搗精時間が長くな ることが報告されているが (Tohno-oka et al. 2004), 「CDCFibar」の捣精時間は「キラリモチ」や「もっちりぼし」 よりも短く, 精麦白度はこれらの品種と同程度に高く, かつ搗精後の砕粒発生がほとんどなく精麦品質が優れて いた.「Azhul」は晚生の六条裸麦で, 短㷏であるが倒伏 しやすく，脱穀時の穀皮の取れやすさ（脱ふ性）が著し く悪い欠点があり (データ略), $\beta$-グルカン含量は「もっ ちりぼし」程度であった。「Tsema」は粳性の六条裸麦 で，早生であるが長稆で，硝子率が高く，精麦白度が $36.7 \%$ と低かった。「Tsema」の $\beta$-グルカン含量は「キラ リモチ」並であったが，粳性の「ユメサキボシ」よりも 高い值を示した。なお，「CDC-Alamo」,「CDC-Fibar」, $\lceil$ Azhul」, 「Tsema」は，品質ランク区分に拈ける裸麦の容 積重の基準值 $840 \mathrm{~g} / 1$ を下回ったが，「CDC-Alamo」と 「CDC-Fibar」は「ユメサキボシ」と同様に二条オオムギ であり，この容積重の基準值は六条裸麦を対象として設 定された值であるため, 六条オオムギよりも大粒の二条 オオムギでは達成しにくいものと考觉られる.

以上のことから，「CDC-Fibar」は「ビューファイバー」 並の高 $\beta$-グルカン含量を示す品種で, 収量性が高く, 穀 粒には不良な形質が認められず，整粒歩合が高くて精麦 加工適性も優れるなど（図 1)，麦飯だけでなく大麦粉や シリアル食品までの汎用的な用途を目指した高 $\beta$-グルカ ン品種育成のための育種素材として, 優れた品質特性を 持つ有望な遺伝資源であると考えられる。ただし，「CDCFibar」は晚生, 長秙で, オオムギ縞萎縮病とらどんこ病 に抵抗性を持たず，赤かび病に対しては感染回避に不利 な開花受粉性（Yoshida et al. 2005）であるなど，日本国 内の品種とは形態, 生態が大きく異なる品種であるため,

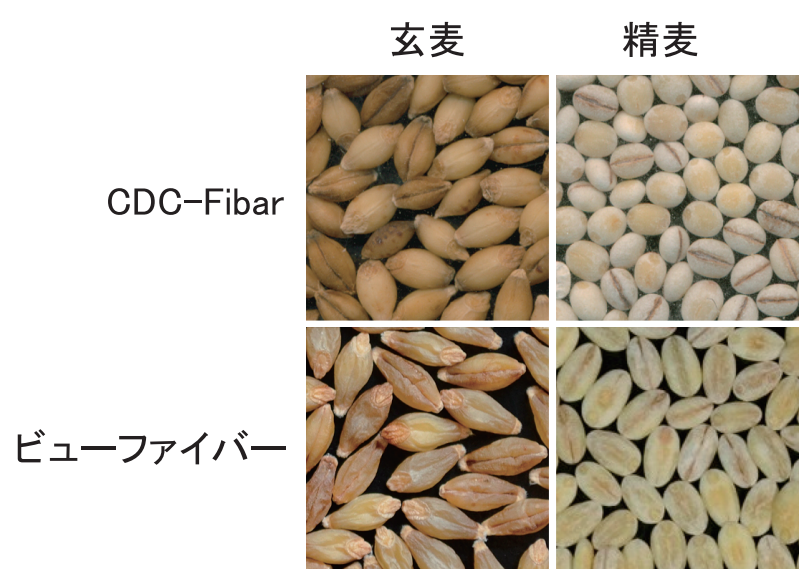

図 1. 高 $\beta$-グルカン育種素材として有望な「CDC-Fibar」扎よび 現行の高 $\beta$-グルカン品種「ビューファイバー」の玄麦と精 麦の外観.
本品種を母本とした場合, 栽培性にも優れた高 $\beta$-グルカ ン品種の育成には長時間を要することが予想される。ま た，「CDC-Fibar」の高 $\beta$-グルカン含量に関与する遺伝子 として, 糯性遺伝子以外は不明であるため, 高 $\beta$-グルカ ン特性に関する効率的で確実な選抜手法がない。そのた め, 本品種の高 $\beta$-グルカン特性に関与する遺伝子の早急 な解明と選抜用 DNA マーカーの開発が課題である.

\section{謝 辞}

本研究の実施に当たり, 農研機構・九州沖縄農業研究 センタ一業務 2 科技術専門職員の日高昭則, 三池啓治, 坂本和彦, 村上栄一, 契約職員の中村耕造の各氏には栽 培管理業務でご尽力いただいた。 また，九州沖縄農業研 究センタ一水田作研究領域契約職員の宮崎千代子, 中村 香世，島里恵の各氏には調査や品質分析に従事いただい た.また,「Azhul $\rfloor, 「$ Wanubet $\rfloor, 「$ Tsema $\rfloor,\lceil$ Oowa $\rfloor$, $\lceil\mathrm{Jau}\rfloor,\lceil\mathrm{Jao} 」$ の種子はアメリカ合衆国農務省農業調査局 国立植物遺伝資源システムより，「CDC-Fibar」と「CDCAlamo」の種子は Dr. Brian Rossnagel（カナダ・サスカチュ ワン大学）より分譲いただいた，本研究の遂行に多大な 貢献をいただいた関係機関の各氏に厚く謝意を表する. 本研究の一部は, 農林水産省「農林水産業・食品産業科 学技術研究推進事業」の研究課題「大麦における機能性 多糖 $\beta$ - グルカンの遺伝的制御技術の開発（課題番号 26053A)」に和いて実施した.

\section{引用文献}

Aoe, S., Y. Ichinose, N. Kohyama, K. Komae, A. Takahashi, D. Abe, T. Yoshioka and T. Yanagisawa (2017) Nutrition 42: 1-6.

Aoe, S., T. Ikenaga, H. Noguchi, C. Kohashi, K. Kakumoto and N. Kohda (2014) Plant Foods Hum. Nutr. 69: 325-330.

Behall, K.M., D.J. Scholfield and J. Hallfrisch (2004a) J. Am. Coll. Nutr. 23: 55-62.

Behall, K.M., D.J. Scholfield and J. Hallfrisch (2004b) Am. J. Clin. Nutr. 80: 1185-1193.

Behall, K.M., D.J. Scholfield and J. Hallfrisch (2006) J. Am. Diet. Assoc. 106: 1445-1449.

Bolwell, G.P. (2000) Trends Glycosci. Glycotech. 12: 143-160.

Bourdon, I., W. Yokoyama, P. Davis, C. Hudson, R. Backus, D. Richter, B. Knuckles and B.O. Schneeman (1999) Am. J. Clin. Nutr. 69: 55-63.

Canadian Grain Commission (2015) Canada Western/Eastern food barley. [https://www.grainscanada.gc.ca/barley-orge/varieties/ designation-en.htm]

Cavallero, A., S. Empilli, F. Brighenti and A.M. Stanco (2002) J. Cereal Sci. 36: 59-66.

Eslick, R.F. and S.E. Ullrich (1977) Barley Genet. Newsl. 20: 39-45.

福原育夫 - 池永 武 - 野口洋樹 - 小梯知英子 - 小長井里織 - 前 佛佳菜子・富田晋平・甲田哲之（2013）薬理と治療 41: 789-795.

Fujita, M., E. Domon and Y. Doi (1999) Breed. Sci. 49: 217-219.

European Food Safety Authority (2009) EFSA J. 7: 1254. 
Hallfrisch, J.G., D.J. Scholfield and K.M. Behall (2003) Nutr. Res. 23: 1631-1642.

Henry, R.J. (1987) J. Cereal Sci. 6: 253-258.

一ノ瀬靖則・金子成延 - 小前幸三（2015）育種学研究 17 (別 2): 209.

Ishikawa, N., J. Ishihara and M. Itoh (1995) Barley Genet. Newsl. 24: $49-53$.

Liljeberg, H.G.M., Y.E. Grandfeldt and I. Bjork (1996) J. Nutr. 126: 458-466.

McIntosh, G.H., J. Whyte, R. McArthur and P.J. Nestel (1991) Am. J. Clin. Nutr. 53: 1205-1209.

中田 克 - 池田達哉・一ノ瀬靖則 - 関 昌子・青木秀之 - 加藤 常夫・小前幸三・長嶺 敬（2018）育種学研究 20（別 1）： 225.

Newman, R.K., C.W. Newman and H. Graham (1989) Cereal Foods World 34: 883-886.

Patron, N.J., B. Greber, B.F. Fahy, D.A. Laurie, M.L. Parker and K. Denyer (2004) Plant Physiol. 135: 2088-2097.

Pins, J., J.M. Keenan, L.L. Curry, M.J. Goulson and L.W. Kolberg (2005) Prev. Control 1: 131.

Swanston, J.S., R.P. Ellis and S.A. Tiller (1996) Barley Genet. Newsl. 27: 72-74.

Tada, R., Y. Adachi, K. Ishibashi, K. Tsubaki and N. Ohno (2008) J. Agric. Food Chem. 56: 1442-1450.

Taketa, S., T. Yuo, T. Tonooka, Y. Tsumuraya, Y. Inagaki, N. Haruyama, O. Larroque and S.A. Jobling (2012) J. Exp. Bot. 63: 381-392.

Taniguchi, K., K. Komae, A. Takahashi, T. Yoshioka and Y. Sone (2017) J. Phys. Anthro. 36: 17-27.

Tohno-oka, T., N. Kawada and T. Yoshioka (2004) In Spunar, J. and J. Janikova (eds.), Proc. 9th Int. Barley Genet. Symp., Brno, Czech Republic, 595-600.
Tonooka, T., E. Aoki, T. Yoshioka and S. Taketa (2009) Breed. Sci. 59: 47-54.

塔野岡卓司（2010）オオムギにおける機能性多糖含量高含有品 種育成のための遺伝・育種学的研究. 筑波大学生命科学研 究科博士学位論文.

塔野岡卓司・吉岡藤治・青木恵美子 - 小前幸三・一ノ瀬靖則・ 金子成延・河田尚之・吉田めぐみ（2011）育種学研究 13: 74-79.

円谷陽一・木原 誠・永倉英彦・川嶋か汪る・東海林義和 (2014) 食品と科学 56: 28-34.

Ullrich, S.E., J.A. Clancy, R.F. Eslick and R.C.M. Lance (1986) J. Cereal Sci. 4: 279-285.

U.S. Food and Drug Administration (2006) Fed. Reg. 71: 2924829250.

Yanagisawa, T., T. Nagamine, A. Takahashi, T. Takayama, Y. Doi, H. Matsunaka and M. Fujita (2011) Breed. Sci. 61: 307-310.

柳澤貴司・青木恵美子・平 将人（2016）米麦改良 2016 年 7 月 号 : 9-12.

吉川 亮・中村和弘・八田浩一 - 中村 洋 (1998）東北農業研 究 51: 97-98.

Yokoyama, W.H., C.A. Hudson, B.E. Knuckles, M.M. Chiu, R.N. Sayre, J.R. Turnlund and B.O. Schneeman (1997) Cereal Chem. 74: 239-296.

Yoshida, M., N. Kawada and T. Tohnooka (2005) Euphytica 141: 217-227.

参考統計資料

厚生労働省大臣官房統計情報部（2015）平成 26 年 患者調査（傷 病分類編）。 [http://www.mhlw.go.jp/toukei/saikin/hw/kanja/ 10syoubyo/]

消費者庁機能性表示食品制度届出データベース. [http://www.caa. go.jp/policies/policy/food_labeling/foods_with_function_claims/.] 